\title{
Size matters: the ethical, legal, and social issues surrounding large-scale genetic biobank initiatives
}

\author{
Klaus Lindgaard Hoeyer \\ Department of Public Health, University of Copenhagen, Denmark \\ E-mail: klho@sund.ku.dk
}

\begin{abstract}
During the past ten years the complex ethical, legal and social issues (ELSI) typically surrounding large-scale genetic biobank research initiatives have been intensely debated in academic circles. In many ways genetic epidemiology has undergone a set of changes resembling what in physics has been called a transition into Big Science. This article outlines consequences of this transition and suggests that the change in scale implies challenges to the roles of scientists and public alike. An overview of key issues is presented, and it is argued that biobanks represent not just scientific endeavors with purely epistemic objectives, but also political projects with social implications. As such, they demand clever maneuvering among social interests to succeed.
\end{abstract}

\section{INTRODUCTION}

Human body parts and tissue samples have circulated in the service of medicine for centuries. During the first half of the $20^{\text {th }}$ century collection efforts gradually changed from focusing on educational anatomical material to the creation of structured research resources more akin to what is today known as biobanks. ${ }^{1}$ Typically, the material was gathered without informing the people in whom it originated; basically, tissue was regarded as a sort of waste product belonging to the health professionals in whose care patients underwent the procedures facilitating its procurement. ${ }^{2}$ During most of the period biobanks have been around they have been almost too mundane and unproblematic to attract any major attention. In the course of the 1990s, however, biobanks gradually became surrounded by more and more intense scholarly debates about ethical, legal and social issues (ELSI). ${ }^{3,4}$ The sudden interest in tissue collections is often explained with increased emphasis on patient rights and the advent of genetic research methodologies. ${ }^{5}$ I wish to suggest that it also reflects a shift in collection size. Some of the new biobanks are much bigger than what individual researchers used to establish on their own, and also existing biobanks increasingly initiate collaborations to improve their statistical strength. The result is a new moral, legal and social landscape. Size might sound like a neutral, objective and purely quantitative matter. It is not.

The drive for larger numbers is largely a consequence of statistical requirements as discussed in an earlier article with a similar title. ${ }^{6}$ These requirements have become more pressing with the increased interest in genetic susceptibility for multi-factorial diseases, because scientists are now dealing with many markers and complex patterns of causation. When we seek to identify the relative importance of many different risk factors, rather than single genes as in e.g. Mendelian diseases, many more persons are needed to identify a pattern and estimate a relative risk. To acquire this statistical strength medical scientists have to collaborate and establish much bigger networks than what has been common in medical research. With large-scale research biobanks, medicine has therefore undergone a transition which in many ways parallels elements of what in experimental physics has been called the transition to Big Science. ${ }^{7}$ As physicists began to request extremely costly equipment to test new theories, they also gradually acknowledged that no individual group of scientists could ever hope to conduct such experiments alone. Epistemic changes and challenges therefore interacted with social requirements as a result of a change in scale. $^{8}$

In 2009 Times Magazine declared biobanking one of the top ten 'ideas changing the world'. ${ }^{9}$ Biobanks do indeed have a potential to change aspects of the world as we know it. They do so through the knowledge production they facilitate but, also, they change the world through the socio-political transfigurations they imply. Indeed, large-scale biobanking involves more than samples and data collection: it is a socio-political and moral endeavor to create the needed political support, public legitimacy and organizational robustness. In this paper I outline some of the ethical, legal and social implications of a change in scale, focusing on consent and benefit sharing, entitlements to the material and challenges related to harmonization and organizational effects and cultural change. Biobanking is a civic project, as it were, through which we change aspects of society - and the emphasis on size that has characterized the past decade of biobanking has only made this point more apparent.

In the following I provide a selective introduction to the field we might characterize as large-scale biobanking ELSI. Other reviews have assessed the biobank literature in general, ${ }^{4,5,10-12}$ so I focus here on the implications of the shift in size. Taking each of the first three ELSI letters, though in reversed order, I end by emphasizing the need for a multi-disciplinary approach to understand the implications of a transition from personal tissue collections to collective 'Big Science' biobanking. 


\section{SOCIAL ISSUES}

To establish a biobank involves a lot of networking: it is a social endeavor. The larger the biobank, the more complex the social maneuvering. Several scholars have tried to come up with new modes of organizing biobanks to facilitate collaboration and ensure incentives for researchers and donors alike., ${ }^{3,13}$ Anne CambonThomsen has suggested introducing a Biobank Impact Factor (BIF, later renamed Biological Resource Impact Factor, BRIF) to incentivize the biobank field and create measures of evaluating biobanks as well as recognizing the work of the people constructing them. ${ }^{14}$ The need for more intense collaboration created by the demand for larger sample sizes has in this way stimulated debate about the basic premises of the social organization of the research community. With the shift in scale, biobanking entrepreneurs have come to seek influence on much more than medical evidence.

Besides the internal structure of the medical research community, the social issues raised through a shift in scale in biobanking include 1) organizational and communicative effects; 2) epistemic and cultural effects of dissemination of research results; and 3) cultural aspects of making sense of the stored material. I will discuss these in turn, but first it is important to acknowledge that the change in scale is part of making biobanks into an arena for public contemplation of each of these issues. When it comes to attracting societal attention, size does matter.

One of the most prominent organizational and communicative effects of large-scale biobanking is the changed mode of engaging ethical issues. Ethics has left the philosophical chamber and become a parameter of competition among researchers and commercial stakeholders. When a Swedish company, UmanGenomics, sought for venture capital, it benefited from having been promoted in Nature and Science as resting on a more robust 'ethics model' than the Icelandic company, deCODE ${ }^{15,16}$ The point is that the change in scale necessitates new forms of maneuvering in relation to potential public opposition and, indeed, proactive 'ethics work' has become a prominent feature of large-scale biobanking. UK Biobank invested in the development of an ethics and governance framework, and several funding agencies have earmarked money to explore ethical issues when initiating large-scale biobanking initiatives. ${ }^{17}$ As ethics turns into a parameter of commercial competition as well as a mode of regulation, the word as such gradually changes its meaning. It has led some to talk about 'empty ethics', ${ }^{18}$ while others have maintained that ethics, even in its new social form, is not empty: it is socially productive and is part of influencing how donors, researchers and governments relate to each other. ${ }^{17,19,20}$

Another communicative effect of large-scale biobanking relates to the tendency for national branding of biobanks. Sometimes biobanks acquire a national identity by their chosen name as in the UK and Estonia; sometimes the national identity is acquired indirectly by appealing to regional or national sentiment in the recruitment process as in some Norwegian, Swedish and Icelandic biobank cases. Alan Petersen suggests a mismatch between national emphasis in recruitment material and the international nature of research, ${ }^{21}$ while other social scientists have been less concerned with this type of criticism and more engaged in understanding the social implications of national rhetoric. Árnason and Simpson, for example, have pointed out the intricate ways in which deCODE became an entry point for renegotiating the Icelandic past as well as visions for the future. The very scale of the project was the impetus for discussing a range of issues including the national economy and identity. ${ }^{22}$

The above described renegotiation of identity relates also to the second set of social implications that this paper will address, namely those associated with epistemic and cultural effects of dissemination of research results. Biobank-based ancestry research, for example, influences social relations as discussed in relation to the Human Genome Diversity Project. ${ }^{23,24}$ When claims to ethnicity influences social entitlements and even legal claims to land, large-scale ancestry research becomes a highly politicized endeavor.

Dissemination of research results also interact with perceptions of health and disease at a more fundamental level by influencing public perceptions of disease, disease causation and the personhood of the affected. For example, most of the research using large-scale genetic biobanks focuses on risk factors, indeed the very change in scale is an effect of this focus, and the category of risk has gradually come to be viewed as a category of disease in its own right in large parts of the public. ${ }^{25,26}$ Novas and Rose have argued that this type of genetic risk information influences perceptions of disease and personhood: we begin to identify with risk numbers and acquire a more somatic sense of personhood. ${ }^{27}$ The 'individual at risk' is in no way related to just genetic biobanking. Indeed from the Framingham Studies onward, knowledge about risk factors such as lipid levels have facilitated new ambiguous disease categories of those who are not-yet-ill (ambiguous because of the slippage between risk factor and the disease itself). ${ }^{28}$ Genetic risk factors have acquired a special status in public debates to such an extent that scholars talk about genetic exceptionalism. ${ }^{29,30}$ It has been pointed out, however, that for many biobank research participants, the genetic material is no more special than the phenotypic information also required to make a biobank into a valuable research resource. ${ }^{31}$ All the same, when biobanks facilitate research into the various risk factors associated with disease, it potentially influences societal conceptions of responsibility, group identity and future options. The larger the biobank, the stronger the statistical strength, the bigger the potential for epistemic changes.

In this way epistemic claims interact with cultural 
change, which is the third set of social implications I will discuss. Large-scale biobanks interact with cultural change in another way too, namely by becoming a new arena for persistent cultural conundrums relating to the relationship between body and person. According to anthropologist Paul Rabinow "The intimate linkage between the two key symbolic arenas, 'the body' and 'the person', would have to figure prominently on any list of distinctively Western traits." ${ }^{32}$ A notion of material continuity between body and person has been contemplated since medieval theology, ${ }^{33,34}$ but in relation to changing topics over time. How persons and bodies relate used to be considered a religious issue having significance for resurrection, while today the body/person relationship is mainly debated in relation to medical procedures. The change of scale in biobanking has increased the public awareness about biobanks and thereby made the collection of tissue into a situation in which donors reflect on the connection between themselves as persons and the donated material. For centuries tissue was collected without informing the people in whom it originated. Just as it was obvious to earlier generations that a tissue sample had no relevance for its source - it was quite simply not considered 'part of' him or her - it is today beyond doubt for most policy makers that the material in the test tube remains "part of" the donor even after the procurement. Today, I would argue, informed consent procedures are part of installing this sense of connection between sample and person: the procedure names and frames the tissue as a piece of the donor. There are no first principles from which we can deduct what is part of whom and for how long. Bodies consist of continuous flows of material, most of which we gladly consider 'waste' after it has left the space we identify as body (some also while inside that space as it is the case with a number of the bacteria on which we are utterly dependent for our survival). ${ }^{35}$ It involves cultural work, i.e. work on patterns of meaning, to make tissue represent persons. Biobanks have become arenas for this type of work, and large-scale biobanks in particular so. When biobanks furthermore acquire a size facilitating claims about national representativity, they potentially come to embody the nation in an almost somatic sense. Biobank freezers can be used metaphorically as a proxy for the surrounding society (I remember once a biobank representative told me that the freezers were where they "kept 80,000 people"), and therefore it is no surprise that large-scale biobanking can become arenas for public negotiation of the duties, entitlements, and mutual obligations between state and citizen. We come to debate much more than what to do with a blood sample, when discussing for example recontact and informed consent. When the sample stands in for the person, we use it to discuss and reflect on societal changes in the relationship between individual, state and market. Such changes imply a call also for legal change.

\section{LEGAL ISSUES}

Some amount of legal ambiguity is often an advantage for an independent researcher or a small research group: a bit of 'rule stretching' is usually part of the game when you venture into the unknown as most researchers aim to do. The shift towards large formal research collaboration creates an altogether different situation. It imposes new demands on accountability. Also, it involves a need for consistency which is not quite as relevant for the lone researcher. When largescale projects need to submit the same project to several research ethics committee they are sometimes met with a problematic variance in committee assessments. ${ }^{36}$ Lack of certainty about rules and regulations therefore makes it difficult to plan complex and expensive large-scale biobank projects, in particular when combining data from several countries. ${ }^{37,38}$ The shift in size therefore involves legal challenges related to 1) harmonization and 2) clarification of entitlements. I will deal with them in turn.

Even if a logic of numbers and statistical strength has translated into a demand for legal change, researchers are not necessarily accustomed to have legislators listening to their legal needs. Still, in relation to cross-national biomedical research there seems to be general support for harmonization of the rules governing biobank research. It is extremely challenging to work across borders when having to adhere to different rules and contradictory guidelines. The question appears to be what to harmonize and how. ${ }^{39}$ Maschke and Murray, however, have challenged the very notion of 'harmonization': ${ }^{40}$ while a seamless legal web is a laudable objective, they argue that the harmonization paradigm rests on a set of assumptions in need of further contemplation. First, will it be good for all stakeholders? Secondly, will new rules acquire legitimacy in all jurisdictions? Thirdly, will harmonization be possible? Fourthly, will 'harmonized' rules be practiced similarly in different contexts? Hoeyer has suggested that the quest for harmonization draws on implicit assumptions about biobanks as somehow similar, though in fact the relations between donor and researcher can be so diverse that from a donor perspective harmonization need not always make sense. ${ }^{12}$ The move towards large-scale population-based biobanks and huge international collaborations might very well, in principle, serve patient interests and yet, in practice, cut the ties between the individual patient and the research community in ways that make researchers less accountable to donor interests. It is a real legal challenge to ensure that the sense of trust characterizing the situation in which a sample changes hands is also reflected in the subsequent cross-national usage. The larger the biobanking project, the greater the challenge.

A common form of cross-national collaboration is known under the name 'trade'. International trade law 
is a complicated matter, but trading generally works pretty well as a mode of collaboration. Trade hinges on clear property rights and thereby takes us on to the topic of clarification of entitlements. There are many commercial interests in the biomedical usage of biobanks, but the legal solutions to the biobank problems cannot draw on a trade model alone, simply because the legal status of human biological material is deeply contested: there is no legal agreement on the extent to which body parts can be considered property - and by whom! ${ }^{41}$ While organs are clearly exempt, some types of tissue are treated as quasi-property, though donors are rarely granted property rights. The legal landscape is embedded in a moral landscape in which most nations try to separate the domain of the person (and by extension also the person's body) from the domain of commodities. Body parts, however, have a hybrid nature transgressing a strict dichotomy. Legal scholars have tried to come up with a number of different solutions to the ambivalent status of stored biobank material. Bovenberg, for example, has suggested providing researchers with unambiguous entitlements to the databases they create, while Laurie has suggested providing donors with property rights to the tissue they donate. $^{42,43}$ No proposal really creates a legitimate solution to the basic problem that the shift in biobanking size has made abundantly clear: there is no unified framework defining who may do what with tissue and bio-information in cross-national collaborations and property law does not deliver tools addressing all articulated interests.

Biobanks in the pharmaceutical sector have not been subject to quite the same legal attention as the independent trusts and those in the public sector. ${ }^{44}$ Some suggest that private-sector biobanks - in particular in the USA - are more or less unregulated. ${ }^{45,46}$ It is not really fair, however, to suggest that legal scholars in general have not paid attention to the private research sector. In fact, legal scholarship has contributed greatly to our understanding of the pros and cons of regulating access to medical resources through market mechanisms. Besides instigating debates about property in the human body, legal scholars have explored the implications of the de facto alternatives to direct ownership, namely Intellectual Property Rights (IPR) and Material Transfer Agreements (MTA). In their famous article on the problems associated with too many patents, the so-called 'tragedy of the anti-commons', Heller and Eisenberg hypothesized that if access to bioinformation would be regulated through a patent regime it could push product development expenditure beyond the market price of the final product. ${ }^{47}$ The hypothesis has been subjected to various forms of empirical testing without giving any definite answers. In a review of this literature, Rebecca Eisenberg finds that there seems to be little evidence for an anticommons effect in academic research simply because academic researchers tend to ignore the risk of patent infringement and go ahead with their research. ${ }^{48}$ When it comes to downstream product development, however, she thinks that the mechanisms associated with the tragedy of the anti-commons have been confirmed, though the degree of the impact is uncertain. Industrial actors are probably more affected than publicly employed researchers, she asserts, which complicates striking a cost-effective balance between in-house biobanking and outsourcing and collaboration in the private sector. ${ }^{49}$ Lisa Ouelette argues that the MTAs, rather than patents, constitute the major hindrance to collaboration. ${ }^{50}$ When biobanks need to comprise samples of several hundred thousand citizens to acquire adequate statistical strength, very few industrial actors will find it optimal to run it in-house with exclusive access. With the shift in biobanking scale, negotiation of MTAs across national boundaries and across the public/private sectors divide therefore becomes a necessary pathway, and few can describe the associated problems and implications as well as legal scholars.

As we will see with ethical issues, to which we now turn, legal scholars seek to balance interests among the researchers themselves as well as among researchers, funders and the donors. Legal aspects cut across all the ethical challenges to which we now turn. In fact, legal scholars have addressed most of ethical issues discussed below, though I have had to leave aside most of this work. ${ }^{51-55}$

\section{ETHICAL ISSUES}

Informed consent has, without doubt, been the most debated issue in biobank ethics during the past decade. $^{5}$ If one finds that a researcher is always obliged to inform a donor about the research in which a tissue sample is enrolled, one should expect this to be equally pressing in small-scale research settings (where doctor and patient know one another) as in large-scale biobanking projects (where donor material is primarily desired to acquire statistical strength and the individual patient is of limited epistemological importance). It seems to be the case, however, that the larger the biobank, the more intense the focus on informed consent. ${ }^{5}$ Ironically, informed consent has become more intensely debated in those population-based research projects where the individual scientifically speaking is less important and the nature of the research more unpredictable (and thus harder to inform about) than in those projects where small and well-identified patient populations have been enrolled in the search for specific disease agents. Even though informed consent is clearly the topic that has attracted most attention in ethics debates, ${ }^{56,57}$ the vocabulary remains contested and the terms have multiplied: some, for example, suggest 'written authorization', ${ }^{58}$ others 'open consent, 59 or 'general consent', ${ }^{60}$ while others again have suggested going for 'public consent' or 'community consent'. ${ }^{61}$

Why then this focus on 'informed consent' (or whatever we should call it) in population-based biobank research? It might be because, informed consent pre- 
scribes a solution: 'deliver information and collect a signature'. Such 'solutions', such standardized organizational recipes, are more and more sought for the bigger the organization gets. Ethical issues, however, rarely come with clear solutions, and in the ethics literature, informed consent represents much more than an apt organizational recipe. It is typically seen as a way to express respect for the individual's autonomy and dignity. From a philosophical perspective, dealing with autonomy and dignity demands much more than a sheet of paper and a signature. ${ }^{62}$ It is therefore important not to conflate ethical concerns with consent procedures. Hence, in the following I discuss what a shift in size implies in relation to respect for 1) autonomy, 2) privacy and 3 ) the common good and benefit sharing. My point will be that consent procedures do not solve the ethical challenges of large-scale biobanking; even if they may represent organizational recipes of great appeal to some researchers and policymakers.

To respect autonomy, you need to identify a person whose autonomy you wish to respect. The fact that we are dealing with research on tissue, not a full person in the usual sense, means that the nature of the person's interest in the tissue must be settled to deduct the nature of the autonomy issue. ${ }^{63} \mathrm{We}$ need to consider why tissue demands respect: is it because it represents the person (almost as a literal extension of the person, $\mathrm{cf}$. the notion of material continuity); or because it belongs to the person who should therefore have his or her wishes respected (similar to respect for intentions behind monetary donations to charities); or is the sense that tissue needs respect only related to the potential risks (mostly informational) that might accrue the donating individual as a result of participation in biobank research? It might also be that respect for autonomy is only a means for ensuring the trust of the donor. Dependent on which of these lines of reasoning you adopt, different biobanks will appear either unproblematic or highly problematic. Small-scale biobanks where patients support the research of their treating physician imply a different set of informational risks than impersonal population-based cohort studies, just as they might generate different expectations in relation to having ones personal preferences respected.

Häyry and Takala focus on the many meanings of autonomy and remind their readers of the differences between the continental tradition (a "Brussels catechism") and the North American principal based approach ("the Georgetown mantra"). ${ }^{64}$ In biobank debates, however, the philosophical understanding of autonomy often remains implicit and thereby also the ethical reasoning behind a given conclusion. Some argue that individual consent will be unnecessary in many instances, ${ }^{65}$ others suggest that contacting the individual is useless, in particular when dealing with the commercial aspects of biobank research. ${ }^{66}$ The dissatisfaction with informed consent as a 'solution' to the problem of ensuring respect for autonomy does not, however, deliver alternative ways of addressing the various aspects of respect for autonomy at stake in biobank research. Some ethicists even suggest that the focus on autonomy in biobank debates has derailed the discussion and sidestepped the virtues of solidarity. ${ }^{67,68}$

In recent years, privacy issues have been explored and it has been pointed out that while the concept of privacy has different meanings in different languages, it clearly reaches beyond mere informational 'risks'. ${ }^{69-}$ ${ }^{71}$ When projects get bigger and when researchers collaborate across borders, people might either feel that they become more anonymous, thanks to the increase in size, or they might in fact feel more dispersed and subject to a loss of control. Informational privacy can relate to individual data or to group-based results that facilitate reinterpretation of group identity as in the case of ancestry research or the etiology of stigmatized disease (see above), and therefore the diverse ethical challenges relating to preservation of privacy cannot be addressed with individual consent. In large-scale cohort studies the individual donor might also serve as part of a control group for research otherwise taking point of departure in disease-oriented biobanks. Members of the control group might very well feel strongly about the disease specific research which is not supposed to relate to them at all, but the question is who should decide what constitutes an infringement of integrity, privacy and autonomy and whether it remains meaningful to focus on individual consent when dealing with population-based biobanks.

The legitimacy of minor infringements is typically evaluated in light of the potential public goods expected to accrue from the biobank endeavor. ${ }^{72}$ This takes us to the topic of the common good. Even without considering ethical infringements, just to be worth the money spent, biobanks need to be useful for the expense to be justifiable. However, there is no agreement on criteria for the assessment of utility, just as there is no agreement on the ideal beneficiaries understood as the people for whom the biobank is expected to be 'useful'. 66 The establishment of criteria for assessing utility cannot be separated from the establishment of a group of intended beneficiaries. With larger projects and with international collaborations this task becomes more and more complicated and, typically, objectives become more and more abstract the more people you need to enroll: to 'further science' or to 'alleviate disease'. Few would question the laudability of such aims, but on the other hand there is no crosscultural agreement on the purposes that science should serve; on what counts as disease; or on what constitutes treatment rather than, for example, enhancement. ${ }^{73-75}$ The bigger the project, the more diffuse the answers. When an individual doctor gathers samples from his patients, there is a reasonable chance that they can discuss, and agree on, the objective and the future beneficiaries. With a change in project size - and a move toward prospective non-disease specific cohorts - the degree of agreement on these matters decreases. It might feel appealing to claim that larger biobanks 
serve the 'common good' simply by way of being better tools for medical research, ${ }^{76}$ but in effect this sidesteps the relevant ethical analysis because it evades the important questions concerning good for whom and according to which criteria.

In continuation of this topic it should come as no surprise that large-scale biobank projects have given rise to ethical debate about benefit sharing and about fairness in distribution of results. ${ }^{77}$ Who should share which benefits? Fair for whom? What counts as relevant benefits? Clearly, philosophical ethics has a lot to contribute to this debate. In biobank research collaborations, the stakeholders in benefit sharing include the researchers themselves; secondly the donors; thirdly non-participating citizens suffering from the investigated condition; fourthly the surrounding society facing redistribution of resources as a consequence of the potential availability of particular types of medical intervention addressing the needs of some rather than others. Ethicists have provided little attention to analysis of benefit sharing among researchers; it is generally treated as a legal issue. ${ }^{78}$ Rather, concerns have revolved around the relationship to donors, and in particular their rights to feedback of research results. ${ }^{79-82}$ Industry representatives have argued against automatic donor entitlement to research results, highlighting how research results are usually very uncertain and that donors might incur problems acquiring good insurance if they are made aware of particular genetic susceptibilities. ${ }^{83}$ The argument that the knowledge produced will not prove useful for the contributing individual of course runs counter to the arguments typically used when justifying the research.

In line with the so-called 'communal turn' in public health ethics, Widdows et al. have pointed out the need to distinguish between different types of common good, some deriving from the community as such and others of a more aggregate nature that can more easily be divided among stakeholders. ${ }^{84}$ When biobank research delivers high tech solutions to welfare related diseases, biobanks run the risk of supporting what Julian Hart once termed 'the inverse health law' (predicting that the availability of medical care varies inversely with the needs of the population served): those that got shall get. ${ }^{85}$ Furthermore, it has been argued that the Human Genome Project and the gene sequencing efforts in general have had minimal public health impact: the results are too diffuse to provide relevant public health guidance. ${ }^{86}$ If we really wanted to further public health in a cost-effective manner and on a global scale, population-based biobanks are probably not the route to choose. And the people that biobanks seek to help rarely involve the poorest of the poor in lowincome countries, though a few exceptions do of course exist. ${ }^{87-89}$

Besides sharing of medical benefits, the sharing of potential financial benefits is a pertinent issue. ${ }^{90}$ The actual size of financial benefits is contested and only limited amounts of evidence are publically available.
When participants expect researchers to be motivated by commercial interests they are likely to be less interested in donating research material. ${ }^{23,24,38,91}$ Profitoriented research potentially endangers public trust. Nevertheless, the overall research infrastructure, through which large-scale biobanks emerge, is designed to accommodate the profit motive. With an increase in size, the amounts at stake and the needed venture capital only multiply. Therefore, there are good reasons for ethicists to become more engaged in deliberation on monetary benefit sharing and infrastructural design. Informed consent procedures do little to protect donor interests and preserve the common good (however defined).

\section{THE ELSI OF LARGE-SCALE BIOBANKING PROJECTS}

The fact that today we readily identify a set of issues as the ethical, legal and social implications of biobanking, though biobanks for many years seemed to involve no extra-scientific issues can probably be attributed, in part, to a change in scale of biobanking initiatives. The change of scale brings along, interacts with, and is related to a number of other changes. Among them we find changes in research infrastructure and financing. The need to collaborate intimately with industrial actors introduces a process of commercialization that in and by itself involves changes in societal expectations and relations of trust between researchers and donors. ${ }^{92}$ Other changes are technological. Molecular research technologies and information and communication technologies have facilitated the increase of biobanking scale and changed the nature of the issues biobanks can raise. Size therefore goes beyond mere quantitative change, it interacts with qualitative change. And, in some instances, a change in scale just facilitates public and legal attention to problems already known from small-scale tissue-based research. None of these issues can be adequately assessed solely as an ethical, a legal or a social issue. The ELSI of largescale biobanking therefore necessitates a productive dialogue between biobank scientists, ethicists, legal scholars and social scientists. Biobanks have become civic projects through which we negotiate relations between citizens, state and industrial actors; between duties, entitlements, and obligations. ${ }^{93,94}$

It is sometimes said that all this attention suddenly afforded biobanks reflects a crisis of trust; but this framing assumes that people used to trust biobanking scientists. $^{95}$ There is no evidence to support this assumption; rather, it seems to be the case that biobanking has become known to a greater public. ${ }^{96}$ The means for preserving trust, or for deserving trust, are widely debated. ${ }^{97}$ Some work to implement more participatory approaches in line with ideals associated with deliberative democracy. ${ }^{98}$ Others argue that trustworthiness must be ensured through better coordination of monitoring tools and agreement on core norms. 
These approaches can be described as either bottom-up or top-down, but both reflect the ambition of arriving at an optimal governance framework. The question is whether there is any such thing as the one best way for such diverse practices as those making up the biobank field. Each biobank is structured differently and involves its own specific set of stakeholders. Many of the ethical issues discussed in this article have no solution; the legal challenges to coordination across borders involve contradictory local interests; and the social implications reach way beyond the biobanking endeavor and involve societal and epistemic issues. Instead of hoping for a master plan or a final list of ELSIs that may serve as a check list for any future biobanker, this scholarship has raised the general awareness of the potential dangers and enlarged our basket of choices when we seek to address them. This scholarship has demonstrated the need for a concrete analysis in each specific case. It has also illustrated how science is coproduced with new forms of policymaking, and shown how a change of scale has involved a new set of challenges associated with establishing networks among scientists, policymakers, donors, and industry.

While most biobankers - again partly as a consequence of a change in scale - have had to acknowledge that their work is inherently political, the stakeholders they engage when seeking advice should also begin to acknowledge that each of the issues they address require a range of competences. Anthropological work on meaning-making can make us reconsider the cultural specificity of some of the much-debated ethical conflicts about informed consent for example, but it provides us with no tools to address and balance the conflicts. Here we need both ethical guidance and legal advice. Just as biobankers have begun collaborating to a much greater degree, ethicists, legal scholars and social scientists need to appreciate each other's work as they collaborate on the ELSI of large-scale genetic research biobanking initiatives.

\section{ACKNOWLEDGEMENTS}

I would like to thank the editors, Morten Andreasen and an anonymous reviewer for providing useful comments on earlier versions of this paper.

\section{REFERENCES}

1. Lawrence S. Beyond the Grave - The use and meaning of human body parts: A historical introduction. In: Weir RF, ed. Stored Tissue Samples. Ethical, Legal, and Public Policy Implications. Iowa: University of Iowa Press, 1998; 111-142.

2. Hoeyer K. After novelty: The mundane practices of ensuring a safe and stable supply of bone. Science as Culture 2010; 19: 123-150.

3. Ashburn T, Wilson S, Eisenstein B. Human tissue in the genomic era of medicine. Arch Intern Med 2000; 160: 3377-3384.

4. Cambon-Thomsen A, Rial-Sebbag E, Knoppers BM. Trends in ethical and legal frameworks for the use of human biobanks. European Respiratory Journal 2007; 30: 373-382.

5. Hoeyer K. The ethics of research biobanking: A critical review of the literature. Biotechnology and Genetic Engineering Reviews 2008; 25: 429-452.

6. Burton PR, Hansell AL, Fortier I, et al. Size matters: just how big is BIG? International Journal of Epidemiology 2009; 38: 263-273.

7. Collins FS, Morgan M, Patrinos A. The Human Genome Project: Lessons from large-scale biology. Science 2003; 300: 286-290.

8. Galison P. Introduction. The many faces of Big Science. In: Galison P, ed. Big Science. The growth of largescale research. Stanford: Standford Unviersity Press, 1992; 1-20.

9. Park A. 10 Ideas Changing the World Right Now: Biobanks. TIME In partnership with CNN 2009.

10. Cambon-Thomsen A. The social and ethical issues of post-genomic human biobanks. Nature Review Genetics 2004; 5: 6-13.

11. Corrigan O, Tutton R. Biobanks and the Challenges of Governance, Legitimacy and Benefit. 2008.

12. Hoeyer K. Donors perceptions of consent to and feedback from biobank research: time to acknowledge diversity? Public Health Genomics 2010; 13: 345-352.

13. Winickoff DE, Winickoff RN. The charitable trust as a model for genomic biobanks. New England Journal of Medicine 2003; 349: 1180-1184.

14. Cambon-Thomsen A. Assessing the impact of biobanks. Nature Genetics 2003; 34: 25-26.

15. Abott A. Sweden sets ethical standards for use of genetic 'biobanks'. Nature 1999; 400: 3.

16. Nilsson A, Rose J. Sweden takes steps to protect tissue banks. Science 1999; 286: 894.

17. Hoeyer K, Tutton R. 'Ethics was here': Studying the language-games of ethics in the case of UK Biobank. Critical Public Health 2005; 15: 385-397.

18. Corrigan O. Empty ethics: The problem with informed consent. Sociology of Health and Illness 2003; 25: 768-792. 
19. Hoeyer K. The role of ethics in commercial genetic research: Notes on the notion of commodification. Medical Anthropology 2005; 24: 45-70.

20. Metzler I. Über „Moralapostel" und „smooth operators": Die praxis der bioethik im feld eines Österreichischen biobankenprojekts. In: Griessler E, Rohracher H, eds. Genomforschung - Politik - Gesellschaft. Wiesbaden: VS Verlag, 2010.

21. Petersen A. Securing our genetic health: Engendering trust in UK Biobank. Sociology of Health and Illness 2005; 27: 271-292.

22. Árnason A, Simpson B. Refractions through culture: The new genomics in Iceland. Ethnos 2003; 68: 533553.

23. Marks J. "We're going to tell these people who they really are": Science and relatedness. In: Franklin S, McKinnon S, eds. Relative Values. Reconfiguring Kinship Studies. Durham \& London: Duke University Press, 2001: 355-383.

24. Reardon J. Race to the Finish: Identity and Governance in an Age of Genomics. New Jersey: Princeton University Press, 2005.

25. Braun B. Biopolitics and the molecularization of life. Cultural Geographies 2007; 14: 6-28.

26. Lupton D. Risk. 1st edn. London and New York: Routledge, 1999.

27. Novas C, Rose N. Genetic risk and the birth of the somatic individual. Economy and Society 2000; 29: 485513.

28. Greene JA. Prescribing by Numbers: Drugs and the Definition of Disease. Baltimore: Johns Hopkins University Press, 2007.

29. Traulsen JM, Björnsdóttir I, Almarsdóttir AB. 'I'm happy if I can help'. Public views on future medicines and gene-based therapy in Iceland. Community Genetics 2008; 11: 2-10.

30. Finkler K, Skrzynia C, Evans JP. The new genetics and its consequences for family, kinship, medicine and medical genetics. Social Science and Medicine 2003; 57: 403-412.

31. Hoeyer K. Conflicting notions of personhood in genetic research. Anthropology Today 2002; 18: 9-13.

32. Rabinow P. Severing the ties: Fragmetation and dignity in late modernity. Knowledge and Society: The Anthropology of Science and Technology 1992; 9: 169-187.

33. Bynum CW. Fragmentation and Redemption: Essays on Gender and the Human Body in Medieval Religion. New York: Zone Books, 1991.

34. Bynum CW. The Resurrection of the Body in Western Christianity, 200-1336. New York: Columbia University Press, 1995.

35. Hird MJ. The Origins of Sociable Life: Evolution After Science Studies. Hampshire: Palgrave Macmillan, 2009.

36. Basu S, Martin SW, Phillips RM, Puri R. Obtaining archived pathological material for biomedical research. Lancet 2003; 361: 1394.

37. Clayton EW. Informed consent and biobanks. Journal of Law, Medicine \& Ethics 2005; 33: 15-21.

38. Elger B, Biller-Andorno N, Mauron A, Capron AM. Ethical Issues in Governing Biobanks: Global Perspectives. Aldershot, England: Ashgate, 2008.

39. Bauer K, Taub S, Parsi K. Ethical issues in tissue banking for research: a brief review of existing organizational policies. Theoretical Medicine 2004; 25: 113-142.

40. Maschke KJ, Murray TH. Ethical issues in tissue banking for research: the prospects and pitfalss of setting international standards. Theoretical Medicine 2004; 25: 143-155.

41. de Faria P. Ownership rights in research biobanks: Do we need a new kind of 'biological property'? In: Solbakk JH, Holm S, Hofmann B, eds. The Ethics of Research Biobanking. Springer, 2009.

42. Bovenberg JA. Property Rights in Blood, Genes and Data: Naturally Yours? Leiden: Martinus Nijhoff Publishers, 2006.

43. Laurie G. Genetic Privacy. A Challenge to Medico-Legal Norms. Cambridge: Cambridge University Press, 2002.

44. Lewis G. Tissue collection and the pharmaceutical industry: investigating corporate biobanks. In: Tutton R, Corrigan O, eds. Genetic Databases. Socio-ethical issues in the collection and use of DNA. London: Routledge, 2004: 181-202.

45. Anderlik MR. Commercial biobanks and genetic research: Ethical and legal issues. American Journal of Pharmacogenomics 2003; 3: 203-215.

46. Barbour V. Who's looking at your DNA? Lancet 2002; 360: 1850.

47. Heller MA, Eisenberg RS. Can patents deter innovation? The anticommons in biomedical research. Science 1998; 280: 698-701.

48. Eisenberg RS. Noncompliance, nonenforcement, nonproblem? Rethinking the anticommons in biomedical research. Houston Law Review 2008; 45: 1059-1099. 
49. Clark BJ, Baust JM, Stacey G. How much will biobanking industry come to rely on private companies? Biopreservation and Biobanking 2010; 8: 179-180.

50. Ouellette LL. Access to bio-knowledge: From gene patents to biomedical materials. Standford Technology Law Review 2010; 1.

51. Gibbons SM, Kaye J, Smart A, Heeney C, Parker M. Governing genetic databases: Challenges facing research regulation and practice. Journal of Law and Society 2007; 34: 163-189.

52. Kaye J. Regulating human genetic databases in Europe. In: Häyry M, Chadwick R, Árnason V, Árnason G, eds. The Ethics and Governance of Human Genetic Databases. Cambridge: Cambridge University Press, 2007: 91-95.

53. Kaye J. Abandoning informed consent: the case of genetic research in population collections. In: Tutton R, Corrigan O, eds. Genetic Databases. Socio-ethical issues in the collection and use of DNA. London: Routledge; 2004: 117-138.

54. Calabresi G. An introduction to legal thought: four approaches to law and to the allocation of body parts. Standford Law Review 2003; 55: 2113-2151.

55. Hartlev M. Sundhedsvidenskabelige informationsbanker. Biobanker. Den Retlige Regulering af Biobanker. Love og Rekommandationer. Copenhagen: Lægeforeningens Forlag, 1996.

56. Diest Pv, Savulescu J. For and against: No consent should be needed for using leftover body material for scientific purposes. BMJ 2002; 325: 648-651.

57. Greely HT. The uneasy ethical and legal underpinnings of large-scale genomic biobanks. Annual Reviews of Genomics and Human Genetics 2007; 8: 343-364.

58. Arnason V. Coding and consent: Moral challenges of the database project in Iceland. Bioethics 2004; 18: $27-$ 49.

59. Nõmper A. Open Consent - A New Form of Informed Consent for Population Genetic Databases. Tartu University, 2005.

60. Wendler D. One time general consent for research on biological samples. British Medical Journal 2006; 332: 544-547.

61. Weldon S. 'Public consent' or 'scientific citizenship'? What counts as public participation in population-based DNA collections? In: Tutton R, Corrigan O, eds. Genetic Databases: Socio-Ethical Issues in the Collection and Use of DNA. London: Routledge, 2004: 161-180.

62. Kristinsson S, Árnason V. Informed consent and human genetic database research. In: Häyry M, Chadwick R, Árnason V, Árnason G, eds. The Ethics and Governance of Human Genetic Databases. Cambridge: Cambridge University Press, 2007: 199-216.

63. Knoppers B, Laberge C. Research and stored tissue. Persons as sources, samples as persons? JAMA 1995; 274: 1806-1807.

64. Häyry M, Takala T. American principles, European values and the mezzanine rules of ethical genetic databanking. In: Häyry M, Chadwick R, Árnason V, Árnason G, eds. The Ethics and Governance of Human Genetic Databases. Cambridge: Cambridge University Press, 2007: 14-36.

65. Eriksson S, Helgeson G. Potential harms, anonymization, and the right to withdraw consent to biobank research. European Journal of Human Genetics 2005; 13: 1071-1076.

66. Corrigan OP, Williams-Jones B. Pharmacogenetics: the bioethical problem of DNA investment banking. Studies in History and Philosophy of Biological and Biomedical Sciences 2006; 37: 550-565.

67. Chadwick R, Berg K. Solidarity and equity: new ethical frameworks for genetic databases. Science in Society 2001; 2: 318-321.

68. Whong-Barr M. Informed consent and the shaping of British and US population-based genetic research. In: Guston D, Sarawitz D, eds. Shaping Science \& Technology Policy: The New Generation of Research. Madison: University of Wisconsin Press, 2006: 291-311.

69. Anderlik MR, Rothstein MA. Privacy and confidentiality of genetic information: What rules for the new science? Annual Reviews of Genomics and Human Genetics 2001; 2: 401-433.

70. Taylor M, Townend D. Issues in protecting privacy in medical research using genetic information and biobanking: The PRIVILEGED Project. Medical Law International 2010; 10: 253-268.

71. Ursin LØ. Privacy and property in the biobank context. HEC Forum 2010; 22: 211-224.

72. Knoppers BM, Joly Y, Simard J, Durocher F. The emergence of an ethical duty to disclose genetic research results: international perspectives. European Journal of Human Genetics 2006; 14: 1170-1178.

73. Brey P. Human enhancement and personal identity. In: Olsen JKB, Selinger E, Riis S, eds. New Waves in Philosophy of Technology. Basingstoke, Hampshire: Palgrave Macmillan, 2008: 169-185.

74. Elliott C. Better than well: American medicine meets the American dream. New York: Norton \& Company, 2003.

75. Hogle LF. Enhancement technologies and the body. Annual Review of Anthropology 2005; 34: 695-716. 
76. Wilson S, Chadwick R. Pursuing equality: questions of social justice and population genomics. In: Häyry M, Chadwick R, Árnason V, Árnason G, eds. The Ethics and Governance of Human Genetic Databases. Cambridge: Cambridge University Press, 2007: 150-157.

77. Simm K. Benefit-sharing: An inquiry regarding the meaning and limits of the concept in human genetic research. Genomics, Society and Policy 2005; 1: 29-40.

78. Wolk S. Biobanksrätt. Lund: Studentlitteratur, 2003.

79. Fernandez CV, Santor D, Weijer C, et al. The return of research results to participants: Pilot questionnaire of adolescents and parents of children with cancer. Pediatric Blood and Cancer 2007; 48: 441-446.

80. Fernandez CV, Skedgel C, Weijer C. Considerations and costs of disclosing study findings to research participants. CMAJ 2004; 170: 1417-1419.

81. Fernandez CV, Kodish E, Weijer C. Informing study participants of research results: An ethical imperative. IRB: Ethics \& Human Research 2003; 25: 12-19.

82. Ravitsky V, Wilfond BS. Disclosing individual genetic results to research participants. American Journal of Bioethics 2006; 6: 8-17.

83. Renegar G, Webster CJ, Stuerzbecher S, et al. Returning genetic research results to individuals: points-toconsider. Bioethics 2006; 20: 24-36.

84. Widdows $\mathrm{H}$, Cordell S. Why communities and their goods matter: Illustrated with the example of biobanks. Public Health Ethics 2011; 4: 14-25.

85. Hart JT. The inverse care law. Lancet 1971; 1: 405-412.

86. Evans JP, Meslin EM, Marteau TM, Caulfield T. Deflating the genomic bubble. Science 2011; 331: 861-862.

87. Chen Z, et al. Cohort Profile: The Kadoorie Study of Chronic Disease in China (KSCDC). International Journal of Epidemiology 2005; 34: 1243-1249.

88. Sirugo G, et al. A national DNA bank in The Gambia, West Africa, and genomic research in developing countries. Nature Genetics 2004; 36: 785-786.

89. Tapia-Conyer R, et al. Cohort Profile: The Mexico City Prospective Study. International Journal of Epidemiology 2006; 35: 243-249.

90. Kattel R. Genetic databases and governance. In: Häyry M, Chadwick R, Árnason V, Árnason G, eds. The Ethics and Governance of Human Genetic Databases. Cambridge: Cambridge University Press, 2007: 236-245.

91. Cunningham H. Colonial encounters in postcolonial contexts. Critique of Anthropology 1998; 18: 205-233.

92. Thacker E. The global genome. Biotechnology, politics, and culture. Cambridge, Massachusetts: MIT Press, 2005.

93. Gaskell G, Gottweis H. Biobanks need publicity. Nature 2011; 471: 159-160.

94. Gottweis H, Zatloukal K. Biobank governance: Trends and perspectives. Pathobiology 2007; 74: 206-211.

95. Petersen A. Biobanks' "engagements": engendering trust or engineering consent? Genomics, Society and Policy 2007; 3: 31-43.

96. European commission. Europeans and Biotechnology in 2010. Winds of change? Brussels, 2010.

97. O'Neill O. Autonomy and Trust in Bioethics. Cambridge: Cambridge University Press, 2002.

98. Secko DM, Preto N, Niemeyer S, Burgess MM. Informed consent in biobank research: A deliberative approach to the debate. Social Science \& Medicine 2009; 68: 781-789.

99. Gibbons SM. From principles to practice: Implementing genetic database governance. Medical Law International 2008; 9: 101-109. 